In the Special Issue on Multicultural Social Justice Leadership Development Guest Editor: Carlos P. Zalaquett, University of South Florida

\title{
A Social Justice Approach to School Counseling
}

\section{Dana Griffin}

The University of North Carolina at Chapel Hill

\section{Sam Steen}

The George Washington University

\begin{abstract}
Based on the 2010 Multicultural-Social Justice Leadership Development academy presentation, this article focuses on how school counselors can collaborate with critical stakeholders to help mitigate barriers to academic success for low-income students and students of color. The overarching goal of the presentation was to define social justice, collaboration, and present a multicultural-social justice approach to school-family-community collaboration. The presenters were two school counselor educators, a mental health counselor educator, and a college/university counselor educator who all believed in the necessity of working together in order to help promote academic achievement for all students. In this article, barriers to social justice advocacy, strategies for implementing a social justice framework, and implications for school counselor practice and research are discussed.
\end{abstract}

Keywords. social justice; collaborative action; academic success, low-income students, barriers, advocacy leadership

Students of color and those living in poverty stricken communities continue to be marginalized within our public schools. Educational reform efforts have not been successful at closing achievement and opportunity gaps for students of color and those from low-income backgrounds (House \& Martin, 1998). It is commonly accepted that numerous polices have been implemented to address the educational inequities that exist (e.g., No Child Left Behind), but systemic injustices still remain. Furthermore, a rich body of research demonstrates that 
students are impacted by numerous social, psychological, and environmental factors (Coleman et al., 1966), and that the current policies in place do not adequately attend to the complex issues that some students must face on a daily basis (Teale \& Scott, 2010). Some of these issues include poverty, family distress, violence, and other conditions outside of schools that affect student achievement (Couillard, Garnett, Hutchins, Fawcett, \& Maycock et al., 2006; Flowers \& Flowers, 2008).

Responding to student needs by only focusing on improving schools does not guarantee the drastic changes necessary to enhance student educational outcomes (Noguera, 2003). A growing body of research highlights the necessity of schools to address the relationship between the academic challenges students face, and factors related to racial and cultural background and socioeconomic status (Noguera, 2008).

If our educational system intends to fulfill its commitment to serving all students, especially those on the fringes of society, and intends to live up to its promise of providing vital avenues of access and opportunity, school counselors, in conjunction with other important school stakeholders, must use their unique educational backgrounds and strategic position in schools to make meaningful change in their schools. In addition to training and preparation, school counselors must rely on their personalities, experiences, values, beliefs, and emotions (Paisley \& McMahon, 2001).

To combat achievement discrepancies, school counselors and other school stakeholders must view these problems within the context of all the systems students are involved in (e.g., school, family, and community) (Noguera, 2003). Moreover, schools cannot successfully tackle these problems without integrating the efforts of schools, families, and communities (Bryan, 2005; Griffin \& Farris, 2010; Griffin \& Steen, 2010). Indeed, the American School Counselor Association (ASCA) adopted the position that stipulates the role of school counselors in promoting, facilitating, and advocating for school-family-community partnerships to help meet all student needs by stating that school counselors must:

Become knowledgeable about community resources and actively pursue collaboration with family members and community stakeholders; remove barriers to the successful implementation of school-family-community partnerships (e.g., mistrust and miscommunication between parties, resistance to the concept and practice, transportation and childcare issues, accessible meeting times); and serve as an advocate, leader, facilitator, initiator, evaluator, and collaborator to create, enrich, and evaluate the effect of these partnerships on student success (ASCA, 2010, pg. 43).

School counselors and other school personnel have to expand or change how they respond to student needs. Targeting students' academic struggles in isolation from external factors (e.g., issues occurring outside of school) limits schools in addressing all of the needs of students in a way that builds on the assets of students and their communities (Adelman \& Taylor, 2002; Griffin \& Farris, 2010). Excessive turnover rates of teachers, principals, central office administrators, and other staff (Porter \& Soper, 2003), poor teacher quality, low morale, negative school climates (e.g., disproportionate referral and expulsion of students of color), and limited family involvement cripple the capacity of schools to meet the vast needs of students (Gregory, Skiba, \& Noguera, 2010). Schools that do successfully educate poor and minority 
children explore internal and external factors (Steen \& Noguera, 2010). Therefore, school counselors must strategically tackle the educational challenges students face by engaging family, community members, and agencies in the school in to help close the achievement gap and strengthen the surrounding community (Steen \& Noguera, 2010).

\section{Defining Social Justice withinthe Context of the Role of a School Counselor}

Social justice is based on the belief that all people in the world are equally valuable, have human rights worth recognizing and respecting, and deserve to live in a just and democratic society of equal opportunity (Ratts, DeKruyf, \& Chen-Hayes, 2007). A social justice approach is warranted to meet the myriad of needs of students, families, and communities (Bemak, 2000). School counselors who are social justice change agents have the beliefs, attitudes, knowledge and skills to identify and take responsibility for eradicating systemic barriers by first recognizing the educational inequalities that exist for students of color and those from low-income environments (Ratts et al., 2007). Further, social justice change agents have an awareness of their own worldviews and biases as well as the desire to become more culturally skilled and knowledgeable at advocating on behalf of and promoting the empowerment of their students and families (Arredondo et al., 1996; Ratts et al., 2007). School counselors infusing social justice ideals into their work must also be culturally competent and willing to learn a variety of components (e.g. values, history, beliefs) of other cultural groups representing the students and their families with whom they work.

Despite a vast body of literature that stresses the importance of school counselors in addressing inequities that exists in schools (Bailey, Getch, \& Chen-Hayes, 2003; Cox \& Lee, 2007; Holcomb-McCoy, 2007; Singh, Urbano, Haston, \& McMahan, 2010), few articles provide concrete strategies that school counselors can infuse in their practice (Singh et al., 2010). However, in a study of school counselors who defined themselves as social change agents, Singh et al. found the following strategies that participants used to enact change in their schools (using political savvy to navigate power structures, consciousness raising, initiating difficult dialogues, building intentional relationships, teaching students self-advocacy skills, using data for marketing, and educating others about the role of school counselor as advocate). Yet, more research is warranted because many school counselors face barriers when trying to implement systemic change in the schools. In fact, one of the biggest barriers is the lack of power that school counselors may hold in their schools. Therefore, in the current article, we present action strategies school counselors can use to promote school success for students of color and those from low-income backgrounds. These strategies are based on research, professional experiences, and the discussions that emerged during the Multicultural-Social Justice Leadership Development Academy held at the ACA Conference in 2010. These strategies call for school counselors to function outside of their traditional roles (e.g., individual and group counseling, classroom guidance, scheduling), and to collaborate with critical stakeholders to address educational inequities that can affect academic achievement such as biases and stereotypes towards race/ethnicity, gender, and socioeconomic status (Kiselica \& Robinson, 2001). Next, a summary of the presentation is described as well as the audience feedback and action strategies that emerged. We conclude with implications for school counseling practice and research.

The presentation, jointly conducted with Greg Dietz and Derrick Palladino, focused on how school counselors, clinical mental health counselors, and college counselors can collaborate to 
help mitigate barriers to academic success and promote achievement for students of color and those from low-income backgrounds who may be at risk of academic failure. The overarching goal of the presentation was to collectively define social justice and then to present a multicultural-social justice approach to school-family-community collaboration based on the presenters' professional experiences. The presenters were two school counselor educators, a clinical mental health counselor educator, and a college/university counselor educator. We all believed in the necessity of working together in order to help promote academic achievement for all students at different stages of development. To take this approach, one must first understand the definition of social justice and collaboration. Although numerous definitions of social justice exist, we conceptualized social justice as addressing and combating educational inequities that create barriers for all students achieving academic success (Cox \& Lee, 2007). Moreover, we defined school-family-community collaboration as collaborative relationships in which school counselors, school personnel, students, families, community members and other school stakeholders work jointly to implement school and community based programs and activities that improve student academic achievement directly within schools, and indirectly by attending to the needs that may be hindering students and families from these accomplishments (Adelman \& Taylor, 2000; Bryan, 2005). We expanded this definition by intentionally acknowledging that the focus on serving students and families moved beyond addressing their internal struggles to combating the external factors that may hinder students from being academically successful. After structuring the presentation with a definition of social justice and school-family-community collaboration, the remaining time was dedicated to facilitating a critical discourse on the struggles and successes of engaging in such work. Additionally, time was spent on brainstorming strategies, suggestions, and action plans on moving forward.

During the presentation, many of the participants shared that they felt restricted in their roles, particularly clinical mental health settings, to effect systemic change and instead voiced the idea that change could only occur with buy-in from those in power. More specifically, many of the participants voiced skepticism at what was really in their control to change. For instance, one participant said, "this sounds good in theory, but in reality, what can we change?"

In retrospect, now given the time to reflect further on this notion of who controls the power, our experiences both as former practicing school counselors, and now counselor educators, we realize that there is great difficulty around putting our lofty ideological claims into practice. Just like the participants, we both can readily recall experiences with former school administrators in leadership positions who were the most influential in making changes in the school such as policies that supported inequitable course selection for students of color and those from lowincome backgrounds (e.g., Advanced Placement courses) and disciplinary actions that were disproportionately affecting African American and Latino males in the school.

Therefore, it was no surprise when some of the participants shared the following barriers that they continue to face that can make it difficult to serve low-income and students of color: 1) limited or lack of funding in order to acquire the necessary resources, 2) minimal knowledge and understanding of cultural differences (i.e., SES, race/ethnicity), 3) lack of confidence in leadership abilities, 4) difficulties in knowing what the population needs, 5) not wanting to work outside the boundaries of the institution, 6 ) fear of confronting the status quo and not wanting to bend the rules for some people, 7) being frustrated in taking on a social-justice approach when feeling like you are working in isolation or fighting a never ending battle, 8) lack of 
adequate and effective communication skills and experience, and 9) working with those that continue to have a linear, conservative, or mono-cultural perspective versus a more open, liberal, and inclusive perspective on meeting the needs of students and families. In some cases, the feelings expressed were readily acknowledged as internal struggles for counselors. Interestingly, Bemak and Chung (2008) confirm that some of these individual feelings and fears are common and may be attributed to what they coin as the nice counselor syndrome (NCS), defined as wanting to be more of a problem-solver as opposed to stressing socially just policies that may cause more conflict with other school personnel. In some cases, these fears can cause counselors to choose not to advocate on behalf of underserved populations and instead maintain the status quo that exists in the schools.

Following this critical discourse, which included listening to the participants narratives, validating their concerns, and normalizing their perspectives, we proposed to the participants a call for action in the following manner: In light of the aforementioned struggles and barriers, how do we overcome the power differentials that exist and create barriers to change, in order truly be social justice change agents? What are some action strategies we can take?

Several specific strategies emerged from our discussions: 1) practitioners must first develop an understanding of cultural differences that may exist between various diverse populations as well as within these populations, 2) practitioners must step outside of their traditional roles that emphasize serving students and families in isolation from their surrounding environments, 3) practitioners must develop allies in the community that include professionals, paraprofessionals, and community members, and take a leadership role in establishing strong collaborations that are mutually beneficial to all parties received, and 4) practitioners must facilitate dialogues that encourage direct, open, and honest two-way communications. However, as previously mentioned, we realize that a gap continues to exist between the ideal and reality. As a first step towards eliminating this gap, the first author provided the following professional experiences of ways that inform how she works towards adopting a social justice advocacy emphasis in her work as a counselor educator.

Dana Griffin: As a counselor educator of school counselors, I tell my students during their internship class that change is slow to occur. But if they look around and into current policies in their schools, change does occur. It happens all the time for those who have significant levels of influence. For example, parents in one school district were not happy with the AP courses available for their students, so they lobbied for more course offerings. Just one year later-more AP courses became available. This story is used to illustrate the power of a collective voice. Further, I emphasize that school counselors must lobby. On this accord, each year, the North Carolina School Counselor Association participates in Legislative Day. During this event, the goal is to have school counselors and school counselor trainees from across the state to lobby state senators and representatives on issues of concern to school counselors and the children they serve. My students must select an issue that they would like to lobby on and must actually set up a time to speak to the state senator that represents the district in which they are currently completing their internship. This calls for them to step outside the traditional role of a school counselor, collaborate with stakeholders to gather information on the needs of the school and district, and take a role in discussing important issues with politicians that encourages open, direct, two-way communications. 
I also require my students to conduct an equity audit in the school where they are interning (see Holcomb-McCoy, 2007), in which they assess the areas of inequities that exist, and they must discuss the findings with the school administrator and offer some potential solutions to these problems. This not only encourages students to be reflective, but it also helps them learn how to openly communicate with those in charge and discuss those policies that are actually barriers to promoting school success for low-income and minority students. Students must also develop an advocacy project and collect data to inform their plans. They must take a collaborative approach by working with parents, teachers, community agencies, and other school stakeholders needed to help enact the policy. Finally, they must present this project to the "school board" and discuss why it should be implemented in the school. Although they do not have to formerly implement the project, this project provides them with the knowledge and skills needed to facilitate difficult discussions, provides them with leadership experiences, and learn how to use allies in the community as they take a collaborative approach towards systemic change.

I also tell students that as school counselors, they cannot, alone, effect change, and they must get families and community activists to help generate opportunities to encourage change. I do share that school counselors have limited power, but it should not stop them from helping others to try to effect change in the schools. For example, school counselors can provide the resources needed to help the families themselves navigate and overcome systemic barriers. Additionally, school counselors can advocate for change at school board meetings, or they can campaign for those running for leadership positions and help them to get elected in order for them to have better opportunities to effect change.

\section{Implications for School Counselor Practice}

Based on the literature, audience feedback and discussion, and our own personal experiences, we realize that asking school counselors to become social change agents is asking for school counselors to take on a lot of responsibility and risk. Indeed, for some, asking school counselors to functions as leaders in this endeavor is akin to asking counselors to turn in a letter of resignation. Therefore, we acknowledge that being a social justice change agent is not for everyone. Nevertheless, we continue to challenge school counselors to work in conjunction with other important school stakeholders to effect systemic change when those in charge work just as hard to maintain the status quo.

Unfortunately, research demonstrates that clinical mental health counselors still typically use traditional methods for client sessions and are inadequately addressing the needs of oppressed and disenfranchised individuals (D'Andrea \& Daniels, 2001). It is safe to assume that at this current juncture in our profession the same can be said for school counselors who work in diverse school populations, especially those in low-income and large minority populations (Steen \& Rudd, 2009).

Taking a social justice approach to school counseling calls for school counselors to be prepared to question authority, challenge the injustices they see in their schools, and work collaboratively with each other (Bemak \& Chung, 2008). Based on the feedback from presentation participants, we believe school counselors should be prepared as social justice advocates in their training program, in order to integrate the demeanor needed to be social justice advocates in the field. To help facilitate this, counselor educators should infuse social justice advocacy into their 
mission statement and philosophy and model social justice advocacy in their work (Pennymon, 2005). Further, counselors must be multiculturally competent. Despite the development of the American Counseling Association Advocacy Competencies, counselors and counselor educators often fail to point out how cultural differences continue to play a role in creating or maintaining client problems (Ivey \& Ivey, 2005).

However, we admit that school counselors cannot and should not do this in isolation. They must work in conjunction with others who have the same core beliefs of promoting student achievement for all students. Therefore, school counselors in the face of opposition must also help others lead the charge and take a stand against injustices and inequalities that exist in the schools. Only then will school counselors afford themselves the chance to see change toward transformative ends. Following are some action strategies that emerged from the presentation that school counselors can take as they begin their quest towards becoming social justice change agents. Although all of the strategies do not include information specifically emphasizing collaboration, we believe school counselors cannot act in isolation in order to make the greatest impact. Nevertheless, the action strategies are below:

1) Develop cultural competencies. School counselors must first have, at minimum, basic cultural competencies in order to be social justice change agents.

2) Use data to support your work. School counselors can collect all types of data (e.g., process data, program evaluation data, or school related variables), or use existing data (e.g., attendance data, report cards) to analyze and demonstrate how current policies are not meeting the needs of low-income and minority students of color and those from low-income backgrounds. Our premise is to let the data do the talking. In other words, do not rely on only sharing what you know in words, but also show it with the data. Unfortunately, some school counselors are less likely to collect and analyze data because of a lack of skill (Steen \& Rudd, 2009). If this holds true for you then consider soliciting the support of others who may have this skill set (e.g., technology resource teacher, central office administrator). But do not let the lack of skill prevent the use of data to highlight educational inequities.

3) Gain allies. School counselors would be wise to develop and cultivate the support from others who hold the same core beliefs and a similar mission for exposing and counteracting social injustices. In the end, the time spent on building these relationships should be beneficial because collectively tackling these significant problems may prove to be more successful then going about it by oneself.

4) Speak up. School counselors should learn to let their opinions and oppositions to certain things that occur in the school be known. School counselors should consider attending school board meetings and speaking about inequalities that occur in the school, or writing to their state legislators. However, it is imperative that tentative solutions for these issues are also voiced. Solutions should be presented tentatively because the most strategic solutions will emerge from a collective body of individuals who would be most invested in the problem. Along the same lines, school counselors can help others (e.g., disenfranchised students and families) who may be less likely to share their opinions do so by providing a venue for them. For example, school counselors can use focus groups, written letters, or town hall style meetings for others to give their input. 
5) Educate and empower parents and families. School counselors can provide parents and families with the necessary resources and knowledge about school issues. Parents and families can learn strategies to help their students navigate the school system. Essentially, school counselors can help disenfranchised families to understand and use the same strategies to overcome barriers that other more privileged parents use. For instance, school counselors can teach families the math progression for students in order to know the importance of taking Algebra in Middle school or reaching a level beyond Algebra II. In another example, school counselors can consider helping families understand how to advocate for their children to apply for gifted programs or other supplemental education programs available in the school or school district.

6) Stay politically engaged. School counselors can get involved in the political arena by running for a local educational association, or a community board. Nevertheless, one does not have to be a board member to be aware of and knowledgeable about the current political environment on the local, state and national level concerning issues relevant to the students and families being served. School counselors should remain engaged in the politics impacting their school and surrounding communities. As a result, this involvement will allow school counselors to approach their work more broadly (Steen \& Noguera, 2010). This knowledge base also can inform both short term and long term planning concerning the goals of the school counselor's school counseling programs.

7) Be bold. It is imperative that school counselors not operate in fear. Fear can be paralyzing; therefore, one must be confident in what they believe in and act on it. Rosa Parks is quoted as stating, "I've learned over the years that when one's mind is made up, this diminished fear and knowing what must be done does away with fear." These are words of wisdom that can be used to guide the work of school counselors desiring to advocate on behalf of those often overlooked or underserved in schools.

8) Be persistent. School counselors have to be willing to keep working to remove barriers to systemic change even in the face of opposition or when it feels like no progress is being made. Moreover, it is inevitable there will be times when one may feel like they have no support or are the only ones passionate about the problems. In these moments, school counselors must remember to never give up. The needs of many our nation's schools and communities are so great that any victory no matter how small, or no matter how long it takes, is well worth it.

9) Conduct research. School counselors have the knowledge, skills, and available data to conduct the necessary research that can demonstrate the needs for more equitable practices.

\section{Implications for Research}

Therefore, one way to gain buy-in from important school stakeholders and to emphasize the necessity for a social justice counseling approach is by using action research data (Dahir \& Stone, 2009; Whiston, 2002). Action research data can provide counselors with the information needed to develop and implement programs that contribute to systemic change (Dahir \& Stone, 2009). Action research is a cyclical process that includes developing a hypothesis, gathering data, interpreting the data and then applying the results to improve practice (Dahir \& Stone, 2009; Sagor, 2005). 
School counselors, using action research in a social justice approach, can incorporate some of the action strategies listed, and provide the evidence needed to show how their interventions help or hinder students of color or low-income students. In addition to disseminating the data to school administrators, school counselors can also disseminate the data at school board meetings, state level conferences and meetings, and state departments of education. Some action research questions counselors can explore include:

- What are the effects of tracking on student academic engagement, motivation, and self-concept?

- What are the effects of working with both mental health counselors and university counselors on African American, Latino, and low-income students' high school graduation rates and college-going rates?

- What internal and external differences exist between African American, Latino, and low-income students who attend college versus those who do not?

- What do teachers, administrators, and other school staff see as the most important goals to work on in the school?

- What are the effects of parental involvement on African American, Latino, and low-income student's high school graduate rates and college-going rates?

School personnel who use action research can be instrumental in promoting school reform, rather than accepting the status quo (Marzano, 2003). Further, using data to inform practices and develop equitable programs and policies allows school counselors to highlight inequities in schools and therefore engage in social justice advocacy work (Dahir \& Stone, 2009).

\section{Conclusion}

The Multicultural-Social Justice Leadership Academy provided a great environment for discussing the barriers and challenges to infusing social justice advocacy work into the counseling profession. Both the presenters and participants, who attended the Academy to explore leadership and advocacy dispositions, were able to collectively gain much insight from the professional experiences of all who were involved in this critical discourse. This information was stimulating and afforded the opportunity to consider ideals and realities when confronting resistance and overcoming challenges when serving many of our nation's low-income students and students of color.

In sum, a multicultural-social justice approach to collaboration calls for school counselors to step outside their traditional roles and to collaborate with important stakeholders to ensure access to equitable educational and programming opportunities for all students, regardless of cultural differences such as race, ethnicity, and socio-economic status. Although ASCA has developed a new position statement on collaboration, it does not address the need for a social justice approach to collaboration, nor does it state how to implement this in one's practice (Steen \& Rudd, 2009). In the current article, we provide some action items that may help to combat achievement and opportunity gaps that may exist for students of color and those from low-income backgrounds (Bemak \& Chung, 2008). The Academy provided the chance to engage in an honest dialogue to share this information and this was a great step in the right direction. However, pre-service school counselors and those currently in the field will need to intentionally engage in social-justice collaborative advocacy work to make the greatest impact on their 
schools and surrounding communities. We are aware that we need to have "buy-in" from those in power, who make decisions on policies and procedures in the school. However, we need to also have "buy-in" from those who feel they do not have power, and they need to be aware that they can also have influence in decision-making on policies and procedures in the school as well. Until this occurs, we will continue to fight an uphill battle on the social justice front.

Contact information/Correspondence:

Dana Griffin, Ph.D.

University of North Carolina at Chapel Hill

CB 3500, Peabody Hall

Chapel Hill, NC 27599

Email: dcgriffi@email.unc.edu

Dana Griffin, Ph.D., University of North Carolina; Sam Steen, The George Washington University

\section{References}

Adelman, H., \& Taylor, L. (2002). School counselors and school reform: New directions. Professional School Counseling,5, 235-248.

American School Counselor Association (2010). Position statement: The professional school counselor and school-family-community partnerships. Alexandria, VA: Author.

Arredondo, P., Toporek, R., Brown, S., Jones, J., Locke, D. Sanchez, J., \& Stadler, H. (1996). Operationalization of multicultural counseling competencies. Journal of Multicultural Counseling \& Development, 24, 42-78.

Bailey, D. F., Getch, Y. Q., \& Chen-Hayes, S. (2003). Professional school counselors as social and academic advocates. In B. T. Erford (Ed.), Transforming the school counseling profession (pp. 411-434). Upper Saddle River, NJ: Merrill Prentice Hall.

Bemak, F. (2000). Transforming the role of the counselor to provide leadership in educational reform through collaboration. Professional School Counseling, 3,323 - 331.

Bemak, F., \& Chung, R. C. (2008). New professional roles and advocacy strategies for school counselors: A multicultural/social justice perspective to move beyond the nice counselor syndrome. Journal of Counseling \& Development, 86, 372-381.

Bryan J. (2005). Fostering educational resilience and academic achievement in urban schools through school-family-community partnerships. Professional School Counseling, 8, 219227. 
Coleman, J. S., Campbell, E. Q., Hobson, C. J., McPartland, J., Mood, A. M., Weinfeld, F. D., \& York, R. L. (1966). Equality of Educational Opportunity. Washington, D.C.: Government Printing Office.

Couillard, D., Garnett, J., Hutchins, A., Fawcett, M., \& Maycock, G. (2006). Student risk factors identified by school counselors and student achievement. Alberta Journal of Educational Research, 52, 277-288.

Cox, A. A., \& Lee, C. C. (2007). Challenging educational inequities: School counselors as agents of social justice. In C.C. Lee (Ed.), Counseling for social justice (2nd ed., pp. 314). Alexandria, VA: American Counseling Association.

D'Andrea, M., \& Daniels, J. (2001). Expanding our thinking about white racism: Facing the challenge of multicultural counseling in the 21st century. In J. G. Ponterotto, J. M. Casas, L. A. Suzuki, \& C. M. Alexander (Eds.), Handbook of multicultural Counseling (2nd ed., pp. 289-310). Newbury Park, CA: Sage.

Dahir, C. A., \& Stone, C. B. (2009). School counselor accountability: The path to social justice and systemic change. Journal of Counseling \& Development, 87, 12-20.

Flowers, T. A., \& Flowers, L. A. (2008). Factors affecting urban African American high school students' achievement in reading. Urban Education, 43(2), 154-171.

doi: $10.1177 / 0042085907312351$

Gregory, A., Skiba, R. J., \& Noguera, P. A. (2010). The achievement gap and the discipline gap: Two sides of the same coin?. Educational Researcher, 39(1), 59-68. doi:10.3102/0013189X09357621

Griffin, D., \& Farris, A. (2010). School counselors and school-family-community collaboration: Finding resources through community asset mapping. Professional School Counseling, $13,248-256$.

Griffin, D., \& Steen, S. (2010). School-family-community partnerships: Applying Epstein's theory of the six types of involvement to school counselor practice. Professional School Counseling, 13, 218-226.

Holcomb-McCoy, C. (2007).School counseling to close the achievement gap: A social justice framework for success. Thousand Oaks, CA: Sage Publications.

House, R. M., \& Martin, P. J. (1998). Advocating for better futures for all students: A new vision for school counselors. Education, 119, 284-291.

Ivey, A. E., \& Ivey, M. B. (2005). Wellness and the DSM-IV-TR: A developmental approach for clients in severe distress. In J. E. Myers \& T. J. Sweeney (Eds.), Counseling for wellness: Theory, research, and practice (pp. 217-224). Alexandria, VA: American Counseling Association. 
Kiselica, M. S., \& Robinson, M. (2001). Bringing advocacy counseling to life: The history, issues, and human dramas of social justice work in counseling. Journal of Counseling \& Development, 79, 387-397.

Marzano, R. J. (2003). What works in schools: Translating research into action. Alexandria, VA: Association for Supervision and Curriculum Development.

Noguera, P.A. (2003). City schools and the American dream: Reclaiming the promise of public Education. New York: Teachers College Press.

Paisley, P. O., \& McMahon, H. G. (2001). School counseling for the 21st century: Challenges and opportunities. Professional School Counseling, 5, 106-115.

Pennymon, W. E. (2005). School counselors' perceptions of social advocacy training: Helpful and hindering events: A qualitative study. In N. S. Madu \& S. Govender (Eds.), Mental health and psychotherapy in Africa (pp. 184-208).

Porter, K., \& Soper, S. (2003). Closing the achievement gap, urban schools: Comprehensive school reform connection (No. ED 480 542). Washington, DC: National Clearinghouse for Comprehensive School Reform. Sovenga, South Africa: UL Press of the University of Limpopo-Turfloop Campus.

Ratts, M., DeKruyf, L., \& Chen-Hayes, S. (2007). The ACA Advocacy Competencies: A Social Justice Advocacy Framework for Professional School Counselors. Professional School Counseling, 11, 90-97.

Sagor, R. (2005). The action research guidebook: A four-step process for educators and school teams. Thousand Oaks, CA: Corwin Press.

Singh, A. A., Urbano, A., Haston, M., \& McMahan, E. (2010). School counselors' strategies for social justice change: A grounded theory of what works in the real world. Professional School Counseling, 13, 135-144.

Steen, S., \& Noguera, P. A. (2010). A broader and bolder approach to school reform: Expanded partnership roles for school counselors. Professional School Counseling, 14, 42-52.

Steen, S., \& Rudd, T. T. (2009). Preparing the $21^{\text {st }}$ century school counselor: Alternatives and implications for counselor educators. Counseling and Human Development, 42, 1-19.

Teale, W. H., \& Scott, J. L. (2010). Making urban schools better places for students, teachers, and families: An interview with Charles Payne. The Reading Teacher, 63, 701-704.

Whiston, S. C. (2002). Response to the past, present, and future of school counseling: Raising some issues. Professional School Counseling, 5, 148-155. 